\title{
ЛИТЕРАТУРОВЕДЕНИЕ
}

\author{
БРЕСЛАВЕЦ Татьяна Иосифовна, \\ канд. филол. наук, профессор кафедры японоведения Восточного института - \\ Школы региональных и международных исследований, ДВФУ (г. Владивосток). \\ Электронная почта: breslavets.ti@dvfu.ru
}

ПАНТЕЛЕЕВА Марина Васильевна,

канд. полит. наук, профессор кафедры японоведения Восточного института Школы региональных и международных исследований, ДВФУ (г. Владивосток).

Электронная почта: panteleeva.mv@dvfu.ru

\section{Аллюзив художественной речи в дневнике странствий Мацуо Басё}

УДК 821.521

аллюзив,

интер-

текстуальность,

ономастика,

дневник,

Мацуо Басё

Статья подготовлена при поддержке гранта Японского фонда.

Для иитирования:

Бреславец Т. И., Пантелеева М. В. Аллюзив художественной речи в дневнике странствий Мацуо Басё // Известия Восточного института. 2021. № 2. C. 22-33. DOI https://doi. org/10.24866/2542-1611/2021$2 / 22-33$
DOI https://doi.org/10.24866/2542-1611/2021-2/22-33

В дневнике странствий «Окунохосомити» («По северным тропам", 1694) японского поэта Мацуо Басё (1644-1694) благодаря широкому обращению к прецедентным феноменам формируется имплицитный информационный фон произведения с многослойной семантикой. В дискурсе дневника обнаруживается особая роль ономастики с её культурноисторическим содержанием, богатство интертекстуальных связей, кросскультурных явлений. Дневник отличается повышенной суггестивностью. Соединение эпизодов дневника, консолидация стихов и прозы в едином корпусе нарратива осуществляется ассоциативными методами. Статья посвящена изучению фоновых составляющих художественной речи.

20-го числа 3-й луны 1689 г. японский поэт Мацуо Басё (1644-1694) отправился в путешествие, изложенное в дневнике «Окунохосомити» («По северным тропам», 1694). Поэта сопровождал его ученик Сора (Каваи Согоро, 1649-1710). «Окунохосомити» («Узкая Дорога Северных Провинций») является топонимом и обозначает узкую дорогу вдоль края горы в северо-восточной части Сэндая, ведущую к Исикаве. Этот опасный участок дороги стал символом всех остальных, по которым Басё прошёл, прокладывая свой путь на север [17, c. 295]. Название сочинения выделяет особую роль топонимики в дневнике странствий.

Текст дневника пронизан историческими и литературными реминисценциями. Памятники японской и китайской культуры насыщают произведение легендами, преданиями, мифами, поэзией, формируя ассоциативный пласт дискурса. Изучение национальной истории, культуры и литературы, выяснение кросскультурных феноменов, запечатленных в языке и стиле выдающегося произведения японской словесности, представляется актуальным в ряду современных исследований фоновых знаний.

Аллюзив «Окунохосомити» как специальная категория совокупности имплицитных свойств сочинения не являлся предметом внимательного изучения, несмотря на то что 
дневнику посвящена разнообразная исследовательская литература. Для освещения темы были привлечены работы японских и зарубежных филологов, таких как Имото Ноити, Огата Цутому, Сиранэ Харуо, Ямамото Кэнкити, Д. Кин, Э. Кэменс, И. А. Боронина и др. Дневник переводился на русский язык Н. И. Фельдман [1, с. 415-458] и Т. Л. Соколовой-Делюсиной [8, с. 78-102], на английский язык был переведен Д. Кином [14, с. 18-176].

В статье ставится цель исследовать дневник Мацуо Басё «Окунохосомити» в качестве культурно-исторического свидетельства. Достижению этой цели способствует изучение аллюзива, составляющего информационный фон произведения. В круг задач входит необходимость восстановить филолого-этнографические, культурноисторические, социокультурные и литературные аллюзии - выявить коннотации смыслов в художественной прозе и поэзии как метажанровой целостности лирического дневника странствий. Выдвигается задача проанализировать средства конструирования аллюзива, выделить ассоциативные свойства объединения стихов и прозы, а также соединения эпизодов дневника.

В исследовании учитывается понятие культурно-исторического компонента значения, разработанного в языкознании Н. Г. Комлевым [6], и принимается позиция Е. М. Верещагина и В. Г. Костомарова, обосновавших существование фоновых знаний [3]. Методологической основой анализа интертекстуальных связей служат работы Ю. Н. Караулова [5] и С. Ю. Преображенского [11].

Исследование осуществляется на основе методик дескриптивнокомпаративного анализа с привлечением текстологических и герменевтических разработок ведущих японских филологов - Курияма Риити, Тэруока Ясутака, Накамура Сюндзё, Хори Нобуо, Сугиура Масаитиро, Огино Киёси и др. Предметом обсуждения избраны отдельные эпизоды дневника, в которых аллюзивная составляющая представлена наиболее разнообразно. Источником является текст на старояпонском языке [19, с. 339-386], переводы которого выполнены авторами статьи.

Если говорить о цели путешествия Басё, то исследователи сходятся на том, что на севере он хотел посетить места, где побывал знаменитый поэт Сайгё (Сато Норикиё, 1118-1190) [13, с. 309-310]. По мнению Сиранэ Харуо, Басё был уверен, что близость к известным горам и рекам, воспетым в стихах средневековых антологий, заставит и его прочувствовать то, что испытали другие авторы. Он совершенно не хотел быть первооткрывателем горных вершин или равнин, напротив, он искал места с богатой историей $[15$, с. 65$]$.

Басё вдохновляли не только странствия Сайгё, автора пятистиший танка (короткая песня), но и Соги (Иио Соги, 1421-1502), создателя рэнга (связанные песни), которые состояли в поиске поэтических тем, традиционного мира утамакура (песенное заглавие) - пейзажей и достопримечательностей. Как отметил Эдвард Кэменс, каждая частица поэзии, найденная в памяти веков, придавала сочинениям особенное чувство близости к древности. Это чувство передавалось из поколения в поколение, и диалог, который поэты вели с прошлым, используя утамакура, привносил ощущение старины в настоящее [12, с. 37].

В стилистическом приеме утамакура использовались топонимызачины, но они непосредственно не взаимодействовали с основным содержанием произведения [2, с. 187-188]. В поэзии Басё, напротив, топонимы, ранее выступавшие в качестве утамакура (топонимическая метафора), органически входят в смысловую канву стихотворе- 
ния и сохраняют свой образный потенциал как национально-культурный компонент. Своеобразно используя интертекстуальные и традиционные основы топонимов, Басё отводит им роль минимизированного художественного средства как в поэзии, так и в прозе.

Посещение Никко Басё сопровождает замечанием о происхождении оронима [19, с. 345]. Согласно легенде, здесь два раза в год весной и осенью - случались извержения вулкана, и гору называли Футарасан - Дважды Разрушенная Гора. Священник Кобо Дайси (774-835), основатель буддийской школы Сингон, учредил здесь храм, а гору назвал Никко, что значит «Сияние Солнца». С этого момента землетрясения прекратились. Однако известно, что храм был основан преподобным Сёдо в годы Энряку (782-806) [18, с. 127]. В дневнике отдано предпочтение не историческому факту, а легенде, составляющей культурно-мифологическое пространство аллюзива, позволившего подчеркнуть величие горы и её красоту. Ситуация, отмеченная именем великого святителя, оказывается ложной. Однако она апеллирует к Сайгё, которому посвящен дневник, поскольку этот поэт «избрал для себя школу Сингон и потянулся к её основателю Кобо Дайси как к образцу, которому подражал всю жизнь» [7, с. 184].

Главной достопримечательностью Никко является Тосёгу - синтоистское святилище, построенное в 1617 г., место упокоения сёгуна, Токугавы Иэясу (1542-1616), - объединителя страны. Экклезионим Тосёгу образован от его посмертного имени - Тосё-Дайгонгэн (Великий бодхисаттва, озаряющий Восток).

Ара тоото / Аоба вакаба но / Хи но хикари

あらたうと青葉若葉の日の光

Как торжественно / На зеленой, на молодой листве / Сияние солнца!..

Басё говорит о ярком солнечном свете, хотя Сора в своём дневнике зафиксировал, что день был пасмурным и дождливым [18, с. 118]. Содержание хайку (комические стихи) может быть раскрыто в сопоставлении с предшествующим прозаическим текстом как завершающий его гимн. Топоним Никко (日光) в трёхстишии отсутствует, однако «хи но хикари» (日の光) - «сияние солнца» отсылает к национальной мифологии в качестве конвенционального знака Страны Восходящего Солнца. Этот факт можно интерпретировать как стилистический приём замещения топонима его вещественным значением. Аллюзия выполняет функцию исторической соотнесенности как явление национально-культурного генезиса.

«Сияние солнца» - аллюзия-мифологема, она ассоциативно связана с образом богини Аматэрасу - «Освещающей Небеса», выступающей верховным божеством синтоистского пантеона, и с «Озаряющим Восток» Токугавой Иэясу. В литературе XX в. этот знак-символ активно использовал писатель Мисима Юкио (1925-1970). В романе «Несущие кони» («Хомба», 1969) он не однажды обращается к образу солнечного сияния на зеленой листве, провозглашая торжество тэнноизма [9]. Никко целесообразно отнести к сакральным топонимам, отмеченным религиозным смыслом.

Сакральность подразумевает и слово «тоото» - «торжественно», «возвышенно», «величаво». Выражение «аоба вакаба» - «зеленая листва, молодая листва» осмысляется как обозначение новой эпохи, наставшей после прекращения междоусобных распрей. 
Культурно-историческая аллюзия строится на подборе лексики, создающей национальный фоновый слой текста, - связанный с религией Синто (Путь богов), а также с историей правления Токугавы Иэясу, которому поэт возносит хвалу.

В заключительной части эпизода Басё создаёт аллегорию, говоря о благодатном сиянии, льющемся с небес, о покое, воцарившемся в стране. Аналогия возникает с текстом из летописно-мифологического свода «Кодзики» («Записки о делах древности», 712), рассказывающим о правлении императора Нинтоку (257-399), озирающего владения, наблюдающего, поднимается ли дым над жилищами, благополучна ли страна: «Следил он за дымом и оказал свою милость народу, и доныне зовётся в предании Святым Государем» [10, с. 20]. В итоге следует признать справедливым замечание о том, что «национальнокультурный компонент свойствен именам собственным, пожалуй, даже в большей степени, чем апеллятивам» [3, с. 170].

В дневнике выделяется переход через прославленную заставу Сиракаву [19, с. 350-351]. Уникальность этого короткого эпизода состоит в том, что он наполнен реминисценциями, отсылающими к стихам таких поэтов, как Сайгё, Минамото Ёримаса, Ноин, Фудзивара Суэмити, Содзу, Оэ Садасигэ, Фудзивара Киёскэ. Эпизод начинается интертекстуальным фрагментом - цитатой «как-нибудь в столицу» (икадэ мияко э) - из стихотворения Тайры Канэмори (ум. в 990 г.):

Таёри араба / Икадэ мияко э / Цугэяраму /

Кёо Сиракава но / Сэки ва коэну то

Если найдётся посланец, / То как-нибудь в столицу /

Известие отправлю / Сказать, что перешёл сегодня / Заставу Сиракаву...

Ситуация соответствует восьмому эпизоду «Исэ моногатари» («Повесть об Исэ», нач. Х в.), рассказывающему о странствии кавалера в провинции Суруге: «И вот подвижник им навстречу. "Каким образом вы здесь, на дороге этой?” - воскликнул он, и видят - знакомец их... Тогда в столицу ей - той даме - письмо кавалер с подвижником послал» $[4$, с. 17]. Привлекается традиционный сюжетный элемент из «прецедентного текста» [5, с. 105-123] - отправление письма в столицу. В дневнике обнаруживается заимствование из двух источников одновременно, что нельзя не оценить как известное свойство традиционной японской литературы.

Для рассказа о заставе Сиракаве привлекается лексика стихотворений танка (короткая песня): осенний ветер, алые клёны, снег, дейция, шиповник, молодая листва на ветвях. Литературный аллюзив оказывается широким, а текст Басё строит как «нанизывание цитат» (иугихаги) - стилистический приём, известный из драматургии театра Но. Поэт осуществляет движение сквозь время и пространство, прибегая к смене живописных картин-воспоминаний.

В завершение эпизода Басё, обозначив автора аллюзивного сочинения, пересказывает историю о человеке, который нарядился для перехода через заставу Сиракаву. Поэт акцентировал важность события, утверждал, что именно эта застава «привлекает сердца утончённых людей», но обычай проигнорировал - не написал необходимого стихотворения.

Свои ощущения, впечатления, настроения Басё доверил образам из стихов других поэтов, в то время как себя представил безликим и 
равнодушным: «успокоилось сердце странника». Кроме того, мастер умолчал об известном сочинении поэта Иио Соги «Путешествие к заставе Сиракава» («Сиракава кико», 1468). В этом случае единственным индикатором аллюзии остался топоним.

Выявленные средства аллюзива - цитирование, нанизывание цитат, пересказ, умолчание - направлены на то, чтобы выразить восхищение видами заставы Сиракавы, запечатленными в произведениях предшествующей литературы. Внушается мысль о том, что ретроспективная картина может быть дополнена и стать обширной, поскольку известно не менее сорока стихотворений различных жанров, посвящённых заставе Сиракаве.

Исключив себя из участников поэтической дискуссии, отстранившись от соперничества, Басё демонстрирует настроение уныния - и весь аллюзив направлен на создание атмосферы «бесконечной печали». В переводе Н. И. Фельдман добавочное имплицитное содержание, намеченное автором дневника, раскрывается с помощью маргинальной глоссы со стихотворениями разных поэтов [1, с. 423-424].

Значение происходящего обнаружится в последующем эпизоде, когда Басё напишет, что его измучили трудности дальней дороги, он устал душой и телом, его увлекли пейзажи, а воспоминания о старине спутали мысли. Поэт сцепляет эпизоды дневника не только линией хронотопа - движением во времени и пространстве, но и общностью тематики и мотивов, развивая их от одного эпизода к другому, как в романе «Гэндзи моногатари» («Повесть о Гэндзи», XI в.)

Басё совершает странствие в сопровождении поэта Сайгё. Он стоит под сенью «ивы у чистой воды», собирает «каштаны, падающие на землю», видит «мискант на засохшем поле», старую вишню в Кисаката и луну над сосной Сиогоси, воспетые Сайгё. Дневник переполняют текстовые аллюзии. Вместе с тем Басё участвует в северном походе Минамото Ёсицунэ (1159-1189), страницы дневника посвящает героям гражданской войны - кланов Тайры и Минамото.

Достигнув Маруямы, поэт обнаруживает руины замка правителя и на кладбище семьи Сато надгробия с именами двух женщин [19, c. 353-354]. Для понимания эпизода нужно обратиться к легенде о сыновьях Сато Мотохару, правителя уезда Синобу, - Сато Цугунобу (1158-1185) и Сато Таданобу (1161-1186). Они сражались на стороне Минамото Ёсицунэ и пали в бою. Чтобы утешить их мать, невестки, облачившись в костюмы воинов и взяв доспехи, продемонстрировали победоносное возвращение погибших мужей. При мысли о мужестве женщин поэт «омочил рукав» (тамото о нурасину). Басё использует традиционный образ увлажнённого рукава как символ пролитых слёз, за которым скрыто всё богатство средневековой японской поэзии.

Он говорит, что «надгробный камень, вызывающий слёзы, не далеко» (даруй но сэкихи мо тооки ни арадзу), и тем самым вспоминает Ян Ху (221-278), китайского сановника, отличавшегося мудростью и добродетелями. Местные жители поставили ему надгробный камень, глядя на который, каждый проливал слёзы. Д. Кин в расширенный перевод предложения помещает топоним, уточняя смысл аллюзии: «One need not go to China to find a gravestone that induced tears» [14, c. 59]. Прецедентный феномен - «камень», ставший денотатом аллю- 
зии, требует восстановления связанной с ним истории, а также имени действующего лица.

В тексте дневника сплетаются японские и китайские предания. Их связь основана на трансформации образа «слёз». К ней можно применить обозначение «смысловая связь» (имидзукэ) - вариант ассоциативной связи строф, практиковавшийся в цепочках связанных стихов (рэнку). У Басё эта связь выступает вариантом уиури - отражения, проекции. Происходит изменение семантики аллюзивного образа и преобразование средств его выражения.

В древнем храме находились исторические артефакты - меч Минамото Ёсицунэ и дорожный короб его оруженосца Бэнкэя:

Ои мо тати мо / Сацуки ни кадзарэ / Каминобори

笈も太刀も五月にかざれ紙幟

Вот и короб, и меч. / Украшай летний день, / Бумажный карп!..

Приближался День мальчиков, в домах выставляли оружие и доспехи, под ветром развевался его атрибут - бумажный карп. Стихотворение транслирует этнокультурный мир традиционного праздника, смысл его предметного содержания выясняется из предисловия к нему (короб, меч) и послесловия (бумажный карп) - пояснений к стихам (котобагаки), подобных тем, что приняты в средневековых антологиях.

Две части эпизода объединяются на основе антитезы - стилистического приёма, широко представленного в дневнике. Мотив скорби сменяется жизнеутверждающим мотивом праздника. Вместе с тем продолжает звучать тема доблести, но с контрастивным элементом: подвигу женщин противополагается геройство мужчин. Структурирование текста, применяемое Басё, восходит, вероятно, к предисловию «Кодзики», выполненному придворным историографом О-но Ясумаро (ум. в 723 г.), в котором каждый из пяти разделов обладает двухчастной композицией, ставшей традиционной [10, с. 19-29].

В дневнике прошлое транспарирует в настоящем благодаря присутствию аллюзивных топонимов. Иногда, как в «Макура но соси» («Записки у изголовья») придворной дамы Сэй Сёнагон (рубеж $\mathrm{X}-\mathrm{XI}$ вв.), достаточно их перечисления, чтобы возникли легендарно-мифологические образы, картины исторических событий или ассоциации со стихами средневековых антологий: переправа Содэ («Сингосюивакасю»), пастбище Обути («Госэнвакасю»), долина Мано («Манъёсю») [19, с. 364]. Все эти топонимы объявлены песенными заглавиями, украшавшими придворную поэзию. Басё старался смотреть даже на самые обычные места с необычной и необыденной точки зрения, соотнося их с поэзией старины $[16$, с. 83].

Переправа Содэ связана с легендой о Минамото Ёсицунэ. Спасаясь от преследователей, он переправился здесь через реку и в качестве платы отдал лодочнику один рукав (coдэ) от своей парчовой одежды. Прибегая к перечислению пройденных мест, Басё убеждает, насколько он спешит к легендарному Хираидзуми. Лапидарный текст вычленяет наиболее значимое, на нем сосредоточивает внимание.

Басё вспоминает о минувшей славе трех поколений рода Фудзивары (XI-XII вв.) в Хираидзуми - Киёхиры, Мотохиры, Хидэхиры, правивших этой областью около столетия [19, с. 364-365]. Последний из правителей, Фудзивара Ясухира, сыграл важную роль в борьбе Минамото 
Ёритомо против Минамото Ёсицунэ. Он напал на замок Ёсицунэ Такадати. Там, где река Коромо впадает в реку Китагами, к северу от храма Тюсондзи, приняли последний бой Ёсицунэ и оруженосец Бэнкэй. Событиями войны эпизод «Хираидзуми» (№ 25) перекликается с эпизодом «Маруяма» (№ 14) по принципу «призыв-отклик» (коо), примененному писателем Кэнко Хоси (1283-1350) в «Цурэдзурэгуса» («Записки от скуки», 1331) - жанре фрагментированной прозы (дзуйхииу). Воплощением темы междоусобных войн стало стихотворение Басё, посвященное павшим воинам:

Нацукуса я / Цувамонодомо га / Юмэ но ато 夏草や兵どもが夢の跡 Летние травы! / Славных воинов / Последний сон...

Басё говорит, что замок лежит в руинах, и только гора Кинкэйдзан сохраняет прежний облик. Поэт увидел запустение, царящее вокруг, и прибег к цитированию - соотнес этот вид со стихотворением Ду Фу (712-770) «Смотрю весной...», в котором автор выступает свидетелем «бедствий земли»:

Страна разрушена, но горы и реки остались,

В крепости весной травы и деревья густы (кусаки фукаси)... [19, с. 364].

По свидетельству Д. Кина, эта цитата, переведённая на японский язык, стала популярной как пословица [14, с. 182]:

Страна разрушена, но горы и реки остались,

В крепости весной травы зелены (кусаао митари)...

Следовательно, высока степень распознания цитаты реципиентом, хотя в оригинальном тексте, ассимилированная с ним, она не маркирована кавычками. Источник аллюзивной цитаты автором не указан, очевидно, в силу ее известности в лингвокультуре дальневосточного сообщества.

Цитату поэт передал адекватно, однако заменил «травы и деревья густы» на «видна зелень трав». Как «центр соответствия» [11, с. 788793] акцентируется лексема «трава» - «куса», она является образом печальной участи воинов. Природа и человеческие деяния свидетельствуют о расцвете и увядании, о возвышении и падении, выражая мысль о бренности бытия. Сора сложил стихотворение об отважном Канэфусе, который сражался рядом с Ёсицунэ:

Унохана ни / Канэфуса миюру / Сирага кана

卯の花に兼房みゆる白髪かな

В цветах дейции / Канэфусу заметил - / Седину его...

Канэфуса, вассал дома Минамото, заботился о жене Ёсицунэ с ее младенческих лет, а жена Канэфусы была кормилицей девочки. Он, несмотря на возраст, сопровождал Ёсицунэ, когда тот бежал с семьей на север. После того как Ёсицунэ покончил с собой, сделав сэппуку (вспарывание живота), Канэфуса, выполняя приказ сюзерена, убил его жену, пятилетнего сына и новорождённую дочь, поджёг дом, где они находились, и сгорел вместе с ними, скрыв следы их пребывания от врагов.

Антропоним является реальным денотатом аллюзивного имени, наделён социокультурными коннотациями. Он аккумулирует идеал преданности и воли, согласно кодексу самурайской чести Бусидо. 
Ассоциации, связанные с этим именем как прецедентным, воспринимаются устойчивыми и социально значимыми. «Унохана» - «дейция» является декоративным кустарником с белыми цветами. Цветовой гаммой объединяются дейция и седина. Облик героя индуцируется белым цветом - символом чистоты в синтоизме.

В монастыре Тюсондзи было два храма - храм Сутр (Кёдо) и храм Света (Хикаридо). После падения дома Фудзивары монастырь Тюсондзи пришел в упадок, однако храм Света пытались сохранить:

Самидарэ но / Фуринокоситэ я / Хикаридоо

五月雨の降りのこしてや光堂

В летних дождях / Устоишь ли ты, / Храм Света?..

Стихотворение, отмеченное экклезионимом Хикаридо, органично вплетается в текст дневника как развитие его сюжета - борьбы света и тьмы. Басё называет храм памятником былого тысячелетия, бросающим вызов и силам природы. Храмы, монастыри и феодальные замки выступают свидетелями исторических или легендарных событий. Пребывающие в руинах, они являются символами бренности бытия (мудзё) - идеи, пронизывающей текст дневника, лежащей в основе его художественно-эстетической концепции.

Далее от горячих источников Наруго Басё предполагает направиться к заставе Ситомаэ [19, с. 365-366]. «Наруго» означает «Крик Ребенка». Согласно легенде, жена Ёсицунэ положила ребенка в короб, и Бэнкэй смог донести его до этого места, прежде чем он впервые расплакался. Застава Ситомаэ получила своё название потому, что именно здесь впервые помочился ребенок Ёсицунэ. Когда опальный герой бежал на север страны, Хидэхира двинулся на его защиту и встретил его в этом пункте. Топонимы Наруго и Ситомаэ, а также Содэ обладают социокультурной этимологией, восходят к самурайским сказаниям, но содержащуюся в них аллюзивную информацию автор не выводит на эксплицитный уровень.

Шёл проливной дождь, и Басё остановился на ночлег в крестьянском доме:

Номи сирами / Ума но ситосуру / Макура мото 蛋䖝馬の尿する枕もと Блохи, вши, / Лошадь мочится / У изголовья...

В первоначальном варианте звукоряд строки был крайне грубым, «ума но барикоку», она словно бы доносила хохот автора. Сора в своём дневнике обозначил вариант «барисуру», но в дальнейшем он был заменен на более мягкое «сито суру» [21, с. 264]. Эвфония хайку стала имитировать шум дождя. Пример показывает снижение эмотивности, расширение автономности стиха, привлекающей реципиента к сотворчеству. Однако Сугиура Масаитиро предлагает принять вариант «барикоку», ощутить в нем острый «аромат» вульгарной провинциальности [18, с. 122].

Лингвопоэтический анализ разговорно-бытовой лексики стихотворения показывает, что «бари (尿) суру» - «мочиться» омонимично «бари (罵䍗) суру» в значении «бранить», «ругать», «поносить», что расширяет смысл высказывания как омонимическая метафора (какэкотоба) классической японской поэзии, усиливает его стилистически сниженный характер. Учитывая особенности японской орфографии и орфоэпии, возможно прочтение иероглифа как «сито (尿) суру» 
(омограф), что позволяет связать трехстишие с топонимом Ситомаэ и с историей Ёсицунэ.

Сезонным является слово «сирами» - «блохи», указывающее на лето. Метод «сезонных слов» (киго) следует расценить как аллюзивный, поскольку в нем зафиксирована символика времен года. Сформированный в раннем японском стихе танка, он стал обязательным для поэзии рэнга и стихов хайку.

Перед тем как войти в город Канадзаву Басё проходит долину Курикару [19, с. 377-378]. Ороним свидетельствует о подвиге Минамото Ёсинаки (1154-1184), атаковавшего здесь войска Тайры в 1183 г. и разгромившего армию противника. В Комацу находится святилище Тада, куда поэт идет на поклонение. Здесь хранится шлем воина Сайто Санэмори (ум. в 1183 г.), служившего дому Минамото, но затем ставшего вассалом Тайры. Он был убит в сражении с Ёсинакой, о котором заботился, когда тот был ребенком. Ёсинака простил Санэмори измену и передал святилищу его шлем - покрытый резьбой, золотой инкрустацией, украшенный наверху серпом:

Мудзан я на / Кабуто но сита но / Киригирису むざんやな甲の下のきりぎりす

Как горестно! / Под славным шлемом - / Кузнечику приют...

Мукаи Кёрай (1651-1704), ученик поэта, придавал большое значение первой строке стихотворения, олицетворяющей, на его взгляд, категорию «неизменного» (фуэки) в эстетике Басё [20, с. 494]. Слово «мудзан» 無残 - «горестный», «жестокий», «ужасный» омонимично буддийскому термину «мудзан» 無慙, означающему попрание религиозных заповедей - действие, совершенное Тайрой Киёмори (11181181), узурпировавшим власть, сжигавшим буддийские святыни. От былого величия не остается следа, и все процветающие гибнут согласно кармическому закону. Полисемантика текста репрезентируется с помощью омофона - одного из вариантов лингвистической аллюзии.

Кроме того, известно, что первоначально Басё использовал выражение «ана мудзан я на» - «о, жестокий рок!», прозвучавшее в пьесе театра Но «Санэмори». Аналогичные высказывания обнаружены в «Хэйкэ моногатари» («Сказание о доме Тайры», 1240) - «ана мудзан» и в «Гэмпэй сэйсуйки» («Сказание о возвышении и падении домов Минамото и Тайры», 1235) - «ана мудзан я» [21, с. 314-315].

Стихотворение, посвящённое самурайским сражениям, несёт переживание ужаса бытия. В нём обнаруживается пафос «неизменного» благодаря лексическому составу, что и отметил Кёрай. Идея присутствия «неизменного» (буэки) в «изменчивом» (рюко) - «вечного в преходящем» (буәки-рюко) разрабатывалась Басё в последние годы жизни как воплощение «великого в малом», была связана с буддийской идеологией. Таким образом, «семантика слова не является простой функцией его структуры, а представляет собой отражение внеязыковой действительности в сознании общества» [6, с. 125]. Аллюзив этого эпизода всецело обращён к японскому эпосу - таким прецедентным текстам, как военно-феодальные эпопеи Японии, повествующие о гибели могущественного клана Тайры.

Следует заключить, что имена собственные играют ведущую роль в тексте произведения, являясь фактором актуализации скрытых смыслов. Можно констатировать, что ономастическая лексика днев- 
ника обладает насыщенным потенциалом значений для передачи информации в сжатом виде.

Дневнику свойственна крайняя фрагментарность, что порождает повышенную суггестивность текста и способствует реализации культурно-исторического и филологического аллюзива. С этой целью активно привлекаются и традиционные средства классического японского стиха. Очевидна высокая интертекстуальная плотность произведения, и его аллюзии, китайские и японские, требуют дополнительных разъяснений.

Сцепление фрагментов дневника происходит на основе принципов ассоциативной связи строф, применяемой для стихотворной цепи рэнку, а также с привлечением достижений средневековой литературы.

\section{Литература}

1. Басё М. Великое в малом. СПб.: Терция; Кристалл, 1999. 512 с.

2. Боронина И. А. Поэтика классического японского стиха. М.: Наука, 1978. $372 \mathrm{c}$.

3. Верещагин Е. М., Костомаров В.Г. Лингвострановедческая теория слова. М.: Рус. яз., 1980.320 с.

4. Исэ моногатари. М.: Наука, 1979. С. $12-84$.

5. Караулов Ю. Н. Роль прецедентных текстов в структуре и функционировании языковой личности // Научные традиции и новые направления в преподавании русского языка и литературы. М.: Наука, 1986. C. 105-123.

6. Комлев Н. Г. Компоненты содержательной структуры слова. М.: КомКнига, 2006. 192 c.

7. Кужель Ю. Л. Мир японского паломничества. М.: МГИИТ, 2012. 328 с.

8. Мацуо Басё. Стихотворения. Проза. М.: Эксмо, 2011. 480 с.

9. Мисима Юкио. Несущие кони. М.: Азбука, 2021. 448 с.

10. Мифы Древней Японии: Кодзики. Екатеринбург: У-Фактория, 2005. 256 с.

11. Преображенский С. Ю. Проблема межтекстовых связей в лингвистическом толковании художественных текстов: аллюзия и цитация // Вестник РУДН. Серия: Теория языка. Семиотика. Семантика. 2017. T. 8. № 4. C. 788-793.

12. Kamens E. Utamakura, Allusion, and Intertextuality in Traditional Japanese Poetry. New Haven, CT: Yale University Press, 1997.
$336 \mathrm{~s}$.

13. Keene D. Seeds in the Heart: Japanese Literature from Earliest Times to the Late Sixteenth Century. N. Y.: Henry Holt and Company, 1999. 1265 s.

14. Matsuo Bashō. The Narrow Road to Oku. Tokyo: Kodansha, 1997. 187 s.

15. Shirane Haruo. Traces of Dreams: Landscape, Cultural Memory, and the Poetry of Basho. - Stanford: Stanford University Press, 1998. 226 s.

16. 井本農一。芭蕉入門。東京、講談 社。1977. 218 c. = Имото Ноити. Знакомство с творчеством Басё. Токио: Коданся, 1977. $218 \mathrm{c}$.

17. 尾形仂。総合芭蕉事典。東京、雄 山閣。 1981. 670 c. = Окада Цутому. Сводный словарь творчества Басё. Токио: Юдзанкаку, $1981.670 \mathrm{c}$.

18. 芭蕉文集。校注：杉浦正一郎、宮 本三郎、荻野清。日本古典文学大系。東 京、岩波。1971. Т. 46.544 с. = Собрание прозы Басё / Под ред. Сугиура Масаитиро, Миямото Санро, Огино Киёси // Серия памятников традиционной японской литературы. Токио: Иванами, 1971. Т. 46.544 с.

19. 松尾芭蕉集。校注 : 井本農一、堀 信夫、村松友次。日本古典文学全集。東 京、小学館。1972. Т. 41.609 c.= Собрание сочинений Мацуо Басё / Под ред. Имото Ноити, Хори Нобуо, Мурамацу Томоцугу // Полное собрание традиционной японской литературы. Токио: Сёгакукан, 1972.

T. $41.609 \mathrm{c}$.

20. 俳論集。校注 : 栗山理一。日本古 典文学全集。東京、小学館。1979. T. 51. 
С. 409-625. = Собрание трактатов о поэзии хайкай / Под ред. Курияма Риити // Полное собрание традиционной японской литературы. Токио: Сёгакукан, 1979. Т. 51.
C. 409-625.

21. 山本健吉。芭蕉。東京、新潮社。 1973. 505 с. = Ямамото Кэнкити. Басё. Токио: Синтёся, 1973. 505 с.

\section{Tatiana I. BRESLAVETS}

Ph.D. (in Philology), Professor, Japanese Studies Department, Oriental Institute - School of Regional and International Studies, Far Eastern Federal University (Vladivostok, Russia).

E-mail: breslavets.ti@dvfu.ru

\section{Marina V. PANTELEEVA}

Ph.D. (in Politology), Professor, Japanese Studies Department, Oriental Institute - School of Regional and International Studies, Far Eastern Federal University (Vladivostok, Russia).

E-mail: panteleeva.mv@dvfu.ru

\section{Allusive Style of the Art Speech in the Travelling Diary of Matsuo Bashō}

UDC 821.521 intertextuality, onomastics,

diary,

The article is written by the support of the Japan allusive style,

Mastuo Bashō Foundation Grant.

DOI https://doi.org/10.24866/2542-1611/2021-2/22-33

The diary of the poet Matsuo Bashō (1644-1694) "Oku no Hosomichi" (“The Narrow Road to Oku”) is full of historical and literary reminiscences. Ancient manuscripts of the Japanese culture enrich the contents of the work, saturate it with legends, myths, and poetry, making the associative layer of discourse. Onomastics plays the leading part in the narration concentrating the polysemousness of the text. The extreme lapidary style is characteristic of the diary, which gives rise to the increased suggestibility of the text and is conductive to the realization of cultural, historical and philological allusions. The high intertextual capacity of the work is evident. The accumulation of the diary episodes takes place on the basis of the principles in associative connection of stanzas, put forward by Bashō for linked verse, and also attracting the achievements of medieval literature.

For citation: Breslavets T. I., Panteleeva M. V. Allusive Style of the Art Speech in the Travelling Diary of Matsuo Bashō // Oriental Institute Journal. 2021. № 2. P. 22-33. DOI https://doi.org/10.24866/2542-1611/2021-2/22-33

\section{References}

1. Basyo M. Velikoe v malom. SPb.: yazykovoj lichnosti // Nauchnye traditsii i Tertsiya; Kristall, 1999. $512 \mathrm{~s}$.

2. Boronina I. A. Poehtika klassicheskogo yaponskogo stikha. M.: Nauka, 1978. 372 s.

3. Vereshhagin E. M., Kostomarov V.G. Lingvostranovedcheskaya teoriya slova. M.: Rus. yaz., 1980. 320 c.

4. Iseh monogatari. M.: Nauka, 1979. S. $12-84$.

5. Karaulov YU. N. Rol' pretsedentnykh tekstov $\mathrm{V}$ strukture i funktsionirovanii novye napravleniya $\mathrm{v}$ prepodavanii russkogo yazyka i literatury. M.: Nauka, 1986. S. 105123.

6. Komlev N. G. Komponenty soderzhatel'noj struktury slova. M.: KomKniga, 2006. $192 \mathrm{s.}$

7. Kuzhel' YU. L. Mir yaponskogo palomnichestva. M.: MGIIT, 2012. 328 s.

8. Matsuo Basyo. Stikhotvoreniya. Proza. M.: EHksmo, 2011. $480 \mathrm{~s}$. 
9. Misima YUkio. Nesushhie koni. M.: Azbuka, 2021. $448 \mathrm{~s}$.

10. Mify Drevnej YAponii: Kodziki. Ekaterinburg: U-Faktoriya, 2005. $256 \mathrm{~s}$.

11. Preobrazhenskij S. YU. Problema mezhtekstovykh svyazej v lingvisticheskom tolkovanii khudozhestvennykh tekstov: allyuziya i tsitatsiya // Vestnik RUDN. Seriya: Teoriya yazyka. Semiotika. Semantika. 2017. T. 8. № 4. S. 788-793.

12. Kamens E. Utamakura, Allusion, and Intertextuality in Traditional Japanese Poetry. New Haven, CT: Yale University Press, 1997. $336 \mathrm{~s}$.

13. Keene D. Seeds in the Heart: Japanese Literature from Earliest Times to the Late Sixteenth Century. N. Y.: Henry Holt and Company, 1999. $1265 \mathrm{~s}$.

14. Matsuo Bashō. The Narrow Road to Oku. Tokyo: Kodansha, 1997. 187 s.

15. Shirane Haruo. Traces of Dreams: Landscape, Cultural Memory, and the Poetry of Basho. - Stanford: Stanford University Press, 1998. 226 s.

16. 井本農一。芭蕉入門。東京、講談 社。1977. 218 s. = Imoto Noiti. Znakomstvo s tvorchestvom Basyo. Tokio: Kodansya, 1977. $218 \mathrm{s.}$
17. 尾形仂。総合芭蕉事典。東京、 雄山閣。1981. 670 s. = Okada TSutomu. Svodnyj slovar' tvorchestva Basyo. Tokio: YUdzankaku, 1981. $670 \mathrm{~s}$.

18. 芭蕉文集。校注：杉浦正一郎、 宮本三郎、荻野清。日本古典文学大 系。東京、岩波。1971. T. 46. 544 s. = Sobranie prozy Basyo / Pod red. Sugiura Masaitiro, Miyamoto Sanro, Ogino Kiyosi // Seriya pamyatnikov traditsionnoj yaponskoj literatury. Tokio: Ivanami, 1971. T. $46.544 \mathrm{~s}$.

19. 松尾芭蕉集。校注：井本農一、堀 信夫、村松友次。日本古典文学全集。東 京、小学館。1972. T. 41.609 s.= Sobranie sochinenij Matsuo Basyo / Pod red. Imoto Noiti, KHori Nobuo, Muramatsu Tomotsugu // Polnoe sobranie traditsionnoj yaponskoj literatury. Tokio: Syogakukan, 1972. T. 41. 609 s.

20. 俳論集。校注：栗山理一。日本古 典文学全集。東京、小学館。1979. T. 51. S. $409-625$. = Sobranie traktatov o poehzii khajkaj / Pod red. Kuriyama Riiti // Polnoe sobranie traditsionnoj yaponskoj literatury. Tokio: Syogakukan, 1979. T. 51. S. 409-625.

21. 山本健吉。芭蕉。東京、新潮社。 1973. 505 s. = YAmamoto Kehnkiti. Basyo. Tokio: Sintyosya, 1973. 505 s. 